\title{
Government Size and Economic Growth in Italy: A Time-series Analysis
}

\author{
Francesco Forte \\ Sapienza-University of Rome; Italian Society of Public Economics; \\ Former Italian Ministry of Finance
}

Cosimo Magazzino

Roma Tre University; Italian Economic Association;

Royal Economic Society

doi: 10.19044/esj.2016.v12n7p149 URL:http://dx.doi.org/10.19044/esj.2016.v12n7p149

\begin{abstract}
The aim of this paper is to empirically assess the relationship between government size and economic growth. Using time series methodologies applied to annual data for Italy, the effect of public expenditure, unemployment, and fiscal reforms on economic activity have been analysed. The data used in these analyses have been collected and shown in Forte (2011). The analysis covered a very long period, 1861-2008. Our results show the presence of a non-linear relationship between the size of the public sector (measured by the share of government expenditure over GDP) and the economic growth rate for Italy. In general, the presence of an inverted "U-shape" curve, which emerges for the last two decades, suggests that expenditure cuts might be faster than GDP dynamic. This result is in line with recent empirical literature on this issue. Interestingly, for the monarchic years, it has been found that the zero budget constraint provoked a slower aggregate income variation.
\end{abstract}

Keywords: Economic growth, fiscal consolidation, BARS curve, Italy, time series

\section{Introduction}

This paper is devoted to the analysis of the very long-run relation between the size of public expenditure and the GDP growth in Italy from 1861, the year in which the Italian state was created, to 2008. Thus, this was the last year before the great economic and financial crisis, which has affected all European Union (EU) countries, generating a sudden reduction of GDP and a corresponding increase of fiscal imbalances as well as the public debt/GDP ratios. The issue of their sustainability has emerged 
particularly in Ireland and in Southern European countries. Prior to the crisis, there was little difference in the bond prices of the various Euro zone countries. The role played by sovereign spreads in the Euro zone has increased dramatically with the onset of the crisis. However, the European Central Bank (ECB) has initiated a program of non-conventional banking refinancing, which has significantly helped the banking system. Also, it has wiped out the default's risk of euro as a whole. European governments, especially the Greek, the Italian, the Spanish, and the Portuguese have ones implemented programs aimed at covering budget deficits and banking refinancing (in the case of Madrid). Nevertheless, the consolidation efforts have caused high unemployment rate and further decrease of GDP. As a result, this increases the debt to GDP ratios. Thus, Italy's debt/GDP ratio before the crisis was gradually diminishing. In 2007, it was close to the $100 \%$ threshold. After the crisis, it was raised continuously; hence in 2014, it exceeded $130 \%$ of the GDP. Subsequently, the question arises on how to pursue a consolidation policy friendly to GDP growth. The main issue is whether the consolidation should be done chiefly by tax increase or by expenditures cuts ${ }^{6}$.

Governments currently absorb a sizeable share of society's resources. On the other hand, throughout history, high levels of economic development have been attained under institutions and various policies that fostered government interventions (Afonso and Jalles, 2011).

While public expenditure, in general, is necessary to have a market economy capable of operating correctly as well in order to foster the aggregate income growth, its continuous expansion cannot be assumed to be consistent with the long-run maximization of GDP growth. Indeed, increase in government expenditure implies an increased tax burden, which may hamper growth, or a deficit that may increase public debt with an increased cost of its service and an increased risk of insolvency. In addition, a growing share of this debt in foreign hands generates a deficit in the current accounts balance of payments that may represent an obstacle to the economic growth. Nevertheless, even if it is true that beyond a given limit, public expenditure may reduce economic growth, it may also improve the quality of GDP. A high rate of growth accompanied by a too unequal distribution of resources could conflict with the objective of maximizing general welfare and social cohesion. Thus, this does not reflect the actual individual preferences of a mature democracy. High defence expenditures may be necessary for some countries to achieve and defend an independent status and their free society

\footnotetext{
${ }^{6}$ The massive spending programs and new regulations adopted by many countries around the world in response to the economic crisis of 2008 have drawn renewed attention to the role of government in the economy (Kahn, 2011).
} 
institutions. In addition, an optimal equilibrium should not necessarily imply the GDP growth maximization and pose the question of the long-run intertemporal optimal distribution of the GDP growth rate.

With this premises, in the remainder of the paper, we analysed the issue of the size of Government expenditure in relation to GDP growth in Italy since 1861. This was done as follows. Section 2 is devoted to discuss recent researches concerning the government size-economic growth nexus. In the following section, the data used in our empirical analyses are shown. Also, they were divided into different periods and sub periods of the 158 years of the Italian state under examination. Thus, this is accompanied with the results and comments. Finally, Section 4 gives the conclusions.

\section{Recent Empirical Findings on the Relationship between Government Size and Economic Growth}

A recent approach to the government size effects on economic growth is centered on the BARS curve (Barro, 1989; Armey, 1995; Rahn and Fox, 1996; Scully, 1994, 1995), which relates the rate of economic growth with government expenditure (as a percentage of GDP). Therefore, this is considered as a peculiar proxy of the State dimension in the economy.

The theoretical foundation of what we are affirming which dates back to the concept of "optimal size of the government", was theorized by Armey who proposed the homonym curve. Analogous to the Laffer's curve (which outlines using a graph of an "inverted U", the relationship between tax revenue and the average tax rate), the Armey's curve shows the relationship between public expenditure (expressed as a share of GDP) and the change in the general welfare of the country (expressed as a rate of economic growth). Therefore, this shows the same shape of a parabola with the concavity facing downwards.

According to Armey (1995), with very low levels of public expenditure, the State would fail to ensure contract compliance and protection of property rights. Hence, it would result in a zero rate of economic growth. On the contrary, with very high shares of public expenditure, citizens would have little incentive to invest and produce. This is made possible since the levels of fiscal burden would be exorbitant, and the growth rate would be affected. Consequently, increase in expenditure which increases at low levels of intervention in the economy, generates a strong boost to economic activity. On the other hand, fiscal expansions at high expenditure levels, results in a slowdown in economic activity. There is, thus, an optimal value of public expenditure share.

Countries can be thought to be either in a "balanced growth" state, in which per capita GDP growth fluctuates around the normal long-term rate of about two percent annually, or in transition - meaning sustained growth in an 
above or below normal rate until they reach the balanced growth state (Kahn, 2011).

Most of the "first generation" empirical literature (prior to the late 90's-early 00's) on the relationship between government size and economic growth has been based on the linear formulation of the link between public expenditure (as a proxy of the size of the public sector) and GDP growth. The evidence provided by this first generation literature is not conclusive, although the number of papers in support of a negative relationship between public expenditure and growth is slightly larger.

In particular, Rubinson (1977), Ram (1986), and Grossman (1988, 1987) found evidence of a positive relationship between public expenditure and growth. Landau (1983), Grier and Tullock (1987), Barro (1990b), and Engen and Skinner (1992) provided evidence in line with a negative relationship. On the other hand, Kormendi and Meguire (1985), and Hsieh and Lai (1994) found no significant relationship.

Alesina and Ardagna (2009), studying the reduction in public debt/GDP ratio in previous episodes of consolidation, have found that in the past, large public debt has been reduced in a rapid way due to sustained growth. This was the case for the reduction of huge public debts of the belligerent countries after World War II and for the U.S. in the Nineties. Substantially, without any increase in tax rates or significant cuts in public expenditure, the large deficit has been turned into a great surplus. A different example is represented by UK consolidation at the end of the World War II, with a debt/GDP equals to $200 \%$. Yet, the country did not suffer a financial crisis due to debt unsustainability; thanks to the confidence given by the markets to UK fiscal authorities (historically believed to be reliable) and the subsequent consolidation realized during the period of the Thatcherian reforms (Magazzino, 2010).

The econometric evidence has shown, in time, that the "progressive consolidation" processes tend to more likely to succeed than a consolidation with "cold shower". Some of these results are probably justified by the introduction of structural reforms. This is alongside with the gradual consolidation and which constitute a determinant of its success.

Empirical results show that the difference in success rates between the two alternative types of consolidation becomes much lower than the average in the case of consolidations. Therefore, this is implemented because of a strong increase in debt. If this is true, countries with higher levels of indebtedness that are facing serious problems of sustainability should opt for a "cold shower" consolidation. This is aimed at re-establishing their credibility as well as their market confidence, so as to contain the "snowball effect”, which otherwise would aggravate their already precarious situation. Due to the limits of tax increase, in relation to their supply side deflationary 
effects on growth, the attention must turn to the expenditure side. Moreover, here it is crucial to explore how much the BARS optimal size of the public expenditure/GDP has been surpassed. Furthermore, the question about the political sustainability of these policies then arises. The Barrios et al. (2011) analysis focused on 14 European countries ${ }^{7}$ dimension, regarding the stance of manoeuvre for each country. Consequently, they considered public expenditure cuts as an instrument of consolidation in a bundle composed of five variables. Therefore, these variables have different weights according to the situation of the considered countries as for: i. the ability to implement expenditure cuts, feasible in countries with a relatively large and inefficient public sector or in states with high levels of social transfers; ii. the possibility to raise revenues, feasible in countries with a contained fiscal pressure or which have significant differences between revenue and expenditure; iii. the possibility of increasing the participation to work by, for example, age retirement (30\%); iv. the possibility of privatizing public assets (5\%); and v. the possibility of pursuing an expansive monetary policy, where the country does not belong to a monetary union (5\%). Furthermore, the results of the econometric analysis conducted allows the division of the analysed countries into four groups: 1) the first group (consisting of Greece, Ireland, Portugal, and Italy) represent countries that face the greatest challenges in fiscal consolidation. Italy and Greece, however, have more leeway than Ireland and Portugal. Italy, in fact, may act both on revenue side (raising taxes in the black economy, estimated at 22\% of GDP) and on labour participation; 2) the second group, which includes France, Germany, Netherlands, Spain, and the United Kingdom, faces a fiscal threat that is moderately high. Hence, this has a lower room for manoeuvre. Worthy of note is the case of Spain, for which the results show a large tax challenge lower than that which was perceived by the markets until 2011. While the country has registered deficits which were very high in recent years, it is also true that before the crisis, between 2004 and 2007, the country had achieved budget surpluses. Despite the rapid increase in debt, it has sufficient room for manoeuvre (increasing the tax rate, relatively low, or both increasing retirement age and occupation); 3) Poland and Hungary form the third group, which is characterized by small fiscal challenges and medium-large room of manoeuvre; and 4) the fourth group includes Sweden, Denmark, and Finland, without any budget threat.

\footnotetext{
${ }^{7}$ The paper considered two dimensions of the issue. The first dimension was based on five variables, each weighted differently: i. the level of debt relative to GDP and to government revenue (with a weight of $30 \%$ and $10 \%$ respectively); ii. the level of the deficit-to-GDP ratio (weight: 25\%); iii. pressures on bond markets, with a distinction between the yields on government bond (10\%) and the share of debt held by foreign investors (10\%); iv. the expected GDP growth (10\%); and v. the indebtedness of private sector-to-GDP (5\%).
} 
The analysis conducted by Forte and Magazzino (2011) revealed that, for the EU-27 member States, the peak of the BARS curve is attained for an expenditure of $37.29 \%$ of GDP, while the average ratio is $47.90 \%$ i.e. 10 p.p. more. For the twelve EU countries for whom an individual time series analysis was meaningful (because of the availability of data), they found that the peak of the BARS curve ranges from 35.39 for Belgium and 35.52 for The Netherlands to 43.50 for UK and 44.47 for Ireland. The minimum deviation from the level of the public expenditure that coincides with the peak of the BARS curve is that of Ireland with only $2.27 \%$, and followed by UK with 7.67 p.p. in excess. The maximum deviation is that of Belgium (of about $18 \%$ ), followed by Denmark (with a percentage of about $17 \%$ ). As for the $27 \mathrm{EU}$ member countries, a country having a public expenditure/GDP ratio above $10 \%$ the peak, on average, suffers a diminution in the GDP growth rate of $2.1 \%$. Moreover, an increase of 1 percentage point in the variation of public expenditure approximately corresponds to a $0.04 \%$ reduction in the acceleration rate of economic activity. However, the considered European countries are very heterogeneous in terms of the peak of the BARS curve.

Empirical findings in Dalena and Magazzino (2012) on the relationship between public expenditure and revenue in Italy between 1862 and 1993 show that the "Tax-and-Spend" argument received empirical support from the liberal period data. In contrast, the interwar years are in line with the "Spend-and-Tax" hypothesis. Finally, the "Fiscal Synchronization" hypothesis emerges in the republican ages.

With regards to the public debt growth nexus in reconstructing a macro regional government deficit of Italy, Buiatti et al. (2014) show that the ultimate cause of the accumulation of the public debt of Italy lies in the extraordinary fiscal imbalance of the Southern regions. The results call for deep institutional reforms of the fiscal decentralization which has so far been implemented in Italy. Kourtellos et al. (2013), investigating the heterogeneous effects of debt on growth using public debt as a threshold variable, found strong evidence for threshold effects based on democracy. Thus, this implies that higher public debt results in lower growth for countries in the Low-Democracy regime. Teles and Mussolini (2014) proposes a theoretical model of endogenous growth that demonstrates how the level of the public debt-to-gross domestic product ratio should negatively influence the effect of fiscal policy on growth. This effect occurs because government indebtedness extracts a portion of young people's savings to pay interest on debts. Wöhlbier et al. (2014) examines potential challenges arising at Member State level from the need and scope for either consolidating on the revenue side or shifting taxes away from labour. Spain, Malta and Slovenia show some room for raising tax, which may be used to 
contribute to fiscal consolidation in addition to expenditure control. Most of the new Member States (the only exception being Hungary) such as Spain and the UK, display tax-to-GDP ratios significantly below the EU average. This is with the UK and Slovenia being very close to the threshold. Such low tax-to-GDP ratios also reflect less generous welfare systems. Belgium, Spain, Luxembourg, Malta, the Netherlands, Slovenia, Finland, and the UK faces strong consolidation challenges due to serious sustainability issues in the medium run or the long-run.

With a different approach, Blume and Voigt (2013) find that constitutionally entrenched spending limits are correlated with lower total government expenditure. Also, the transparency of a nation's budget is correlated with higher government effectiveness as well as lower corruption.

\section{Methodology, Data, and Empirical Results}

In our applied analyses, the ARIMAX (AutoRegressive Integrated Moving Average with Exogenous Variables) models were used. However, it was used together with Newey and West's correction regarding heteroscedasticity and autocorrelation.

Furthermore, we used the data recently reconstructed by Forte (2011) for Italy. In Table 1 below, we presented some descriptive statistics of the relevant public finance' variables: the real GDP growth rate $(y)$, the share of government expenditure over GDP $(G)$, the share of public revenue/GDP $(T)$, the public $(B)$ and fluctuating debt as a GDP ratio, and the primary budget/GDP $(D)$.

Table 1. Descriptive statistics of relevant public finance variables (Italy, 1861-2008)

\begin{tabular}{ccccc}
\hline \hline Variable & Mean & Median & $\begin{array}{c}\text { Inter-Quartile } \\
\text { Range }\end{array}$ & $\begin{array}{c}\text { Standard } \\
\text { Deviation }\end{array}$ \\
\hline $\begin{array}{c}\text { Economic growth rate } \\
\text { Public }\end{array}$ & 2.16 & 2.27 & 5.00 & 6.90 \\
expenditure/GDP & 26.41 & 24.39 & 21.62 & 15.47 \\
Public revenue/GDP & 22.66 & 18.50 & 15.56 & 12.40 \\
Primary budget/GDP & -3.10 & -0.79 & 7.57 & 6.61 \\
Public debt/GDP & 78.49 & 80.61 & 41.96 & 27.58 \\
Fluctuating debt/GDP & 32.07 & 21.39 & 36.79 & 21.78 \\
\hline \hline
\end{tabular}

Source: our elaborations on Forte (2011) data.

However, the average of the 150 years conceals the huge differences in the five periods presented in Table 2. It respectively covers the "incubation age" from 1861 to 1894, the "take off” age from 1896 to 1914, "the industrialization age" from 1919 to 1939, the "neo capitalistic age” from 1946 to 1972, and the "European new age" from 1993 to 2008. During these periods, one should also consider the important political changes which have influenced the Government dimension and the fiscal and monetary policy. The first period, of incubations, has been divided in our analysis into two 
sub-periods. They are the democratic governments of the historical right from 1861 and the sub-period of the democratic governments of the historical left from 1895. Subsequently, the take off period largely coincides with the so-called Giolittian era of centre. In the last part of the period, the first great world war began, which caused an unusual growth in public expenditure and an inflation that reduced the related increase of the public debt GDP ratio. Therefore, the subsequent period for most part coincided with the fascist era. However, in its last part, there was a second great world war with Italy. At the end, the country was divided into two parts. It was largely destroyed which resulted to a successive post war reconstruction. In 1946, the last year of this period, the country's institutional architecture changed from the monarchic form of the state to a republican one. The long subsequent neo-capitalist period, from the political point of view, may be defined as that of the first Republic characterized by the proportional electoral system and the confrontation between the traditional parties. Therefore, this was under the division of the world in the two blocs of the democratic countries and the communist countries. Notwithstanding, in Italy, it had undergo important political changes which influences the government dimension and the fiscal and monetary policy which may imply to subdivide it into three or four sub-periods: the initial one of centre ranging from 1947 to 1961; the second of centre-left ranging from 1961 to 1972; the third subperiod of "national solidarity" ranging from 1973 to 1981; and the fourth of new centre-left ranging from 1982 to 1992. The last period, of the Second Republic, is characterized by the emergence of new parties and political coalitions under the changes of the electoral system and by the problems of difficult reforms required by the membership of the European Monetary Union.

On one hand, we may observe a continuous growth of public expenditure on GDP from $10.7 \%$ in the incubation age, to $17.44 \%$ in the take-off age, and to 23.69 in the industrialization age. Afterwards, it remains at the same percentage in the neo capitalistic age and it jumps to $47 \%$ in the European new age. On the other hand, GDP growth rate which was $0.75 \%$ in the incubation age, increases to $2.37 \%$ in the industrialization age, to $4.25 \%$ in the neo capitalistic age, and decline to $1.43 \%$ in the European new age. Clearly, in the first four periods, the increase of public expenditure on GDP has been accompanied by a GDP growth. Thus, in the last age, the great average increase of public expenditure is accompanied by a more than proportional decline in the GDP growth rate. Obviously, the time distinction in five periods involves arbitrary elements that influence the values of the resulting average changes in the public expenditure to GP ratios and in the GDP growth rates. Nevertheless, what emerges is that the BARS's law as for the effects of the ratio of public expenditure to GDP on the GDP growth rate 
was confirmed. Hence, this was done for Italy long-run trend. However, we need an econometric research to find the BARS curve public expenditure on GDP behaviour and its optimal level.

Figure 1. Public expenditure, revenue, and economic growth (\%, Italy, 1862-1918)

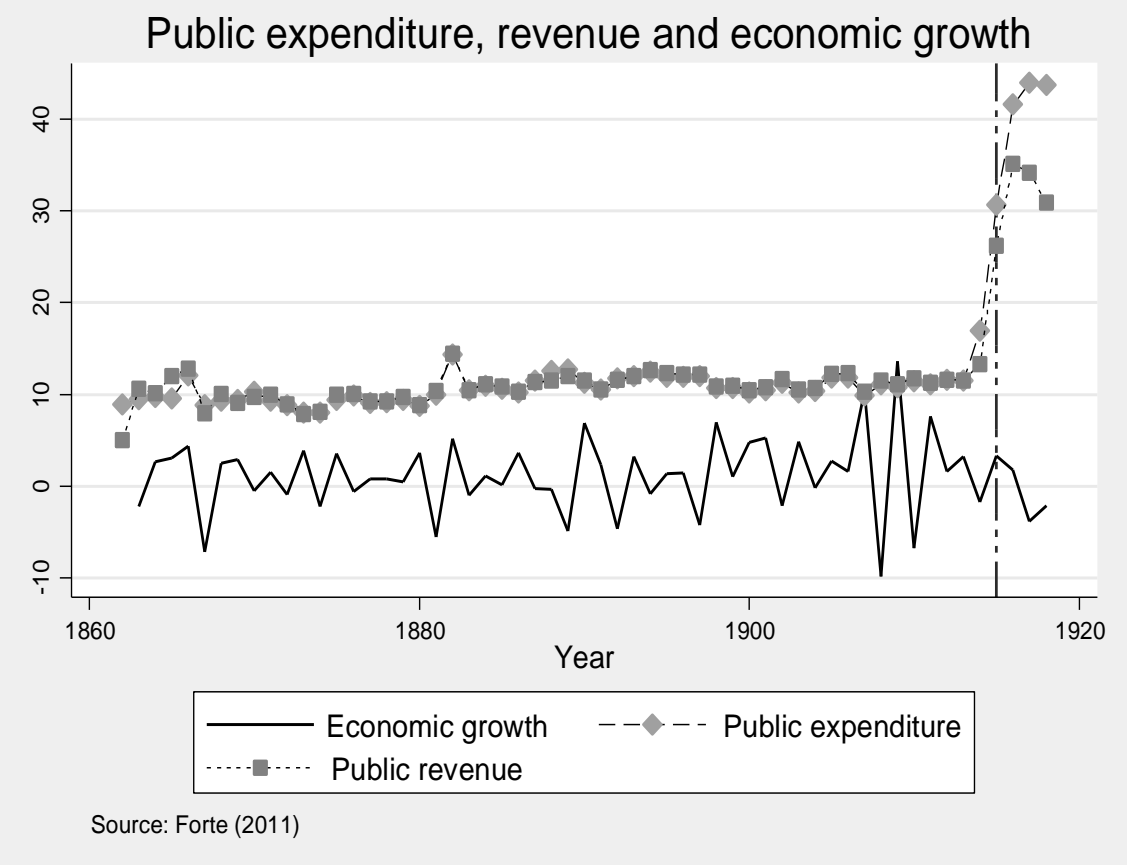

Table 2. Public finance variables and economic growth (Italy, 1861-2008)

\begin{tabular}{|c|c|c|c|c|c|c|c|}
\hline \multicolumn{8}{|l|}{ Mean } \\
\hline Variable & $\begin{array}{l}1861- \\
1876\end{array}$ & $\begin{array}{l}1877- \\
1895 \\
\end{array}$ & $\begin{array}{l}\text { 1896- } \\
1914\end{array}$ & $\begin{array}{l}1919- \\
1939\end{array}$ & $\begin{array}{l}\text { 1946- } \\
1972\end{array}$ & $\begin{array}{l}\text { 1973- } \\
1992\end{array}$ & $\begin{array}{l}1993- \\
2008\end{array}$ \\
\hline $\mathrm{Y}$ & 0.9795 & $\begin{array}{l}0.5938 \\
\end{array}$ & 2.0394 & 2.5848 & 5.1457 & 2.5540 & 1.3292 \\
\hline $\mathrm{G}$ & 9.4029 & 11.0404 & 11.3597 & 21.2117 & 28.4892 & 46.3800 & 49.8063 \\
\hline $\mathrm{T}$ & 9.4715 & 11.0461 & 11.4318 & 19.6194 & 24.8652 & 35.8868 & 45.0926 \\
\hline $\mathrm{D}$ & 0.0687 & 0.0045 & 0.0723 & -4.7254 & -2.4945 & -3.4000 & 3.1668 \\
\hline $\mathrm{B}$ & 64.0867 & 91.8220 & 85.4657 & 100.3404 & 37.5309 & 71.8069 & 110.8746 \\
\hline \multicolumn{8}{|c|}{ Final value-Starting value } \\
\hline Variable & $\begin{array}{l}\text { 1861- } \\
1876 \\
\end{array}$ & $\begin{array}{l}1877- \\
1895 \\
\end{array}$ & $\begin{array}{l}1896- \\
1914 \\
\end{array}$ & $\begin{array}{l}1919- \\
1939 \\
\end{array}$ & $\begin{array}{l}1946- \\
1972 \\
\end{array}$ & $\begin{array}{l}1973- \\
1992 \\
\end{array}$ & $\begin{array}{l}1993- \\
2008 \\
\end{array}$ \\
\hline $\bar{Y}$ & 1.5597 & 0.5917 & -3.1691 & 8.1922 & -10.5184 & -6.1136 & -0.1529 \\
\hline G & 0.9300 & 2.8835 & 4.9593 & -12.2542 & 13.7457 & 19.5000 & -7.2000 \\
\hline $\mathrm{T}$ & 5.0822 & 3.0569 & 1.1578 & -15.1731 & 17.7808 & 15.3046 & -0.0808 \\
\hline $\mathrm{D}$ & 4.4137 & -0.5812 & -5.4952 & 20.3594 & 7.1000 & 6.1000 & -0.1644 \\
\hline $\mathrm{B}$ & 48.7620 & 29.8320 & -32.0552 & -65.0895 & 11.1691 & 54.6314 & -9.0033 \\
\hline
\end{tabular}

The correlation between output growth and public expenditure during the whole period was almost absent $(-0.06$, which, moreover, is the same value assumed by the correlation coefficient in the years 1862-1914), while 
the negative association is also confirmed in the interwar period (-0.25).

In the three sub-periods considered here, the variation in economic activity on an average was equal to $1.35 \%$ between 1862 and 1914, 1.90\% between 1915 and 1947, and 3.53\% between 1948 and 2008. The variation in public expenditure/GDP ratio, however, was equal respectively to $3.51 \%, 0.93 \%$, and $1.65 \%$. Therefore, in the post-unitary and up to the First World War, the highest increase in expenditure/GDP and the lowest growth rate were recorded. Based on the concerns of the average expenditure levels, in the years of Historical Right (1862-1876), the government size was equal to 9.40\%. Then, it grew to $11.09 \%$ with the Historical Left (1877-1896), and to $17.89 \%$ with the Giolitti era and the Great War (1897-1920). Fascism and the Second World War did increase this ratio up to an average of 23.69\% (19211947), whilst between 1948 and 1979, it decreased to 20.16\%. Finally, among 1980 and 2008, there was an excessive increase which led this ratio to 44.32\%.

Figure 2. Public expenditure, revenue, and economic growth (\%, Italy, 1919-2008)

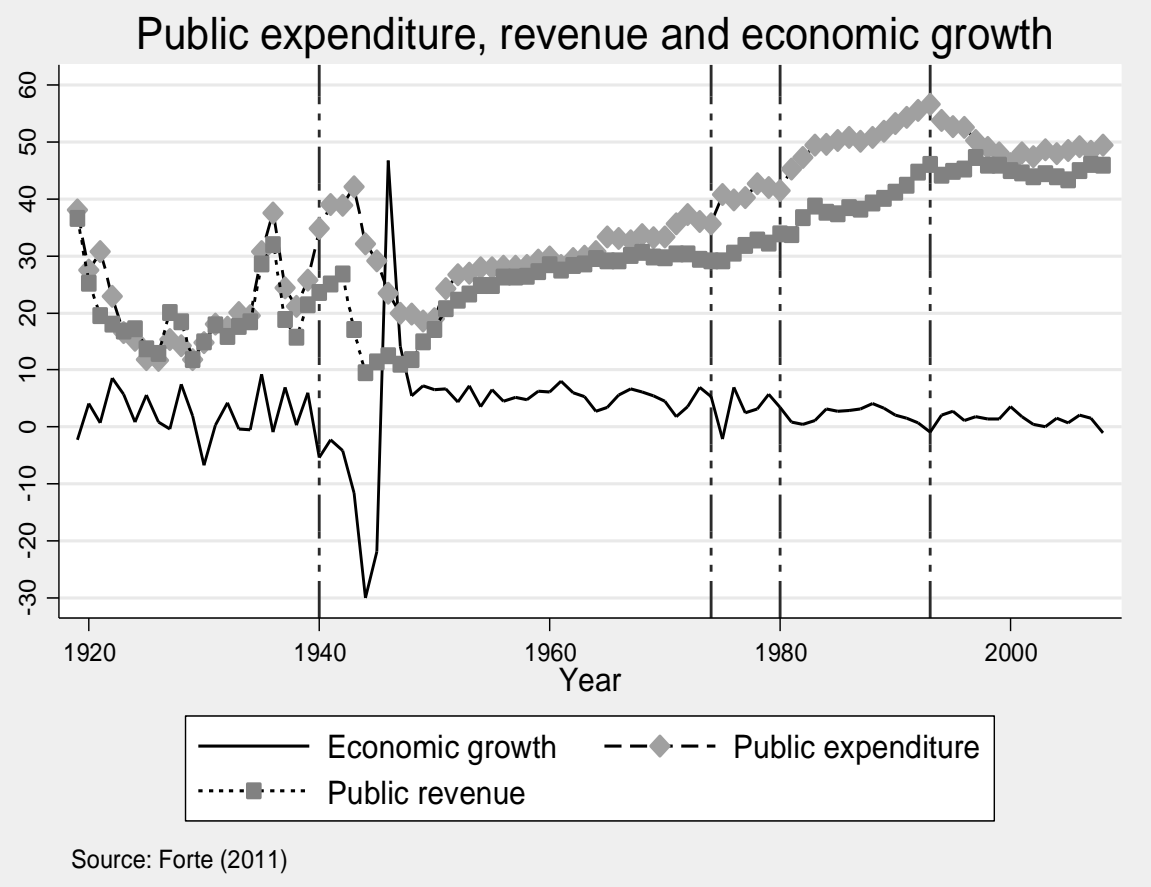

By analysing the dynamics of the budget balance in relation to GDP, it stood on an effective average deficit of $1.97 \%$ during the Historical Right period. Yet, with Historical Left, there were no sudden upheavals as the average deficit was $0.20 \%$. The Giolitti years and the First World War produced a high medium deficit (5.40\%). With fascism, there was a 
subsequent rupture of the combination, since the increase in revenue was lower than that of expenditure which produces a budget deficit equal to 8.47\%. In the period of 1948-1979 together with a decrease in expenditure, there was a stagnation of the average revenue. This was such that the deficit/GDP ratio decreased (3.98\%). Finally, from 1980 to 2008, the robust increase in expenditure has accompanied the less accented increase in revenue which results in marked deficits (7.32\%).

The debt/GDP in 1989 exceeded the threshold of 90\%. Thus, according to Reinhart and Rogoff (2010), it represents a secular weight that has a significant impact on economic growth in the long-run (and often lasts for two decades or more). Since that year, that ratio has not returned below $90 \%$ anymore. Keeping the estimated threshold by Cecchetti et al. (2010) to be equal to $85 \%$, we found that the value was exceeded in 1987 . In addition, the existence of a negative relationship between debt/GDP ratio and output growth in the period 1861-2010 is confirmed by the results of Balassone et al. (2011). Obviously, a bilateral correspondence exists between debt and growth, but the normal recessions last only for one year. Therefore, it cannot explain a period of two decades of malaise. It is more likely that the growth constraints have the origin in the government's need for raising taxes, as well as in lower investment expenditure. Thus, public expenditure provides an incentive in the short term with a secular decline in the long-run.

As the cross-correlograms show, the low correlation of roughly 0 (0.08) represents the correlation between the public expenditure lagged 10 years and the actual real growth rate, or equivalently, the correlation between the actual public expenditure and the real growth rate 10 years ahead. Similarly, a low correlation (-0.09) between 10-lags real economic growth and 10-lags public expenditure was found.

Therefore, the analysis presented here continues with the estimation of possible non-linear effects of public expenditure, assuming that the growth rate is a positive function of aggregate income, but a negative function of its square:

$$
\text { [1] } \quad \mathbf{Y}_{\mathrm{t}}=\boldsymbol{\alpha}+\boldsymbol{\beta}_{1} \mathbf{G}_{\mathrm{t}}+\boldsymbol{\beta}_{2} \mathbf{G}_{\mathrm{t}}^{2}+\gamma \mathbf{U}_{\mathrm{t}}+\boldsymbol{\varepsilon}_{\mathrm{t}}
$$

where: $t$ are the indices associated to each year; $Y$ is the rate of output growth; $G$ corresponds to government expenditure as a percentage of GDP; $U$ is a set of control variable in order to capture the business cycle, such as the unemployment rate; and $\varepsilon_{t}$ is the stochastic component. Thus, the presence of the BARS curve is verified if $\mathrm{H}_{0}: \beta_{1}>0$ and $\mathrm{H}_{0}: \beta_{2}<0$ cannot be rejected.

The second-degree term indicates a diminishing marginal productivity of public expenditure. The share of expenditure on GDP that maximizes economic growth based on quadratic equation in [1] can be deduced by the formula [2]. Thus, after differentiation, the income with 
respect to expenditure is given as:

$$
\text { [2] } \mathbf{G}^{*}=-\mathbf{b} / 2 \mathbf{c}
$$

Table 3. Estimates for the BARS curve (Italy, 1861-1914)

\begin{tabular}{|c|c|c|c|}
\hline $\begin{array}{c}\text { Dependent Variable: } \\
\mathrm{y} \\
\end{array}$ & 1861-1876 & 1877-1895 & 1896-1914 \\
\hline $\mathrm{G}$ & $1.3371 * *(0.6675)$ & $1.5113^{* * *}(0.5458)$ & $\begin{array}{c}1.0243 * * * \\
(0.3994)\end{array}$ \\
\hline$G^{2}$ & $-3.5288 * * *(1.5866)$ & $-4.4504^{* *}(2.0299)$ & $\begin{array}{c}-2.9239 * * * \\
(1.0692)\end{array}$ \\
\hline $\mathrm{T}$ & $6.4573 * * *(1.9567)$ & $\begin{array}{l}2.80871^{* * *} \\
(0.8150)\end{array}$ & $1.8455(1.8565)$ \\
\hline Wars & $\begin{array}{c}-12.4281 * * * \\
(1.9651)\end{array}$ & $2.2157 * *(1.1341)$ & $-2.2328(1.9740)$ \\
\hline Fiscal Reforms & $13.9752 * * *(2.3790)$ & $4.6426^{* * *}(1.2165)$ & $2.6420(1.6874)$ \\
\hline $\mathrm{P}$ & $-1.1123 * * *(0.0876)$ & $-0.8175^{* * *}(0.2314)$ & $\begin{array}{c}-0.8293^{* * *} \\
(0.3052)\end{array}$ \\
\hline Population & $8.5543 * *(4.0666)$ & $5.7867 *(3.52109)$ & $\begin{array}{r}47.0235^{* *} \\
(18.5940)\end{array}$ \\
\hline $\mathrm{D}$ & $0.1578 * *(0.0823)$ & $2.6723 * * *(0.1964)$ & $2.5987 *(1.5839)$ \\
\hline B & $0.2382 * *(0.1337)$ & $1.0151^{* * *}(0.0671)$ & $0.1669 * *(0.0894)$ \\
\hline Constant & $-3.7076 * *(1.9022)$ & $-3.0024 * *(1.4606)$ & $\begin{array}{c}-2.5300^{* *} \\
(1.0159) \\
\end{array}$ \\
\hline $\mathrm{N}$ & 14 & 19 & 19 \\
\hline ARMA & $(1,1)$ & $(1,1)$ & $(1,1)$ \\
\hline Wald $\chi^{2}$ & $(0.0000)$ & $(0.0000)$ & $(0.0000)$ \\
\hline AIC & -91.5192 & -131.357 & -123.6007 \\
\hline $\mathrm{BIC}$ & -97.2707 & -136.0792 & -128.3229 \\
\hline$L$ & 36.7596 & 60.6785 & 56.8004 \\
\hline$\overline{\mathrm{G}}$ & 9.40 & 11.04 & 11.36 \\
\hline $\mathrm{G}^{*}$ & 18.95 & 16.98 & 17.52 \\
\hline $\mathrm{G}^{*}-\overline{\mathrm{G}}$ & 9.55 & 5.94 & 6.16 \\
\hline
\end{tabular}

Applying time series methodologies, the estimates presented in Table 3 show that the optimal public expenditure share from World War II till today, is equal to $40.50 \%$. By including the unemployment rate in the analysis, it drops to $37.39 \%$. Finally, inserting as an explanatory variable, a dummy that controls for enacted tax reforms, we arrive at $35.32 \%$.

Therefore, one can note that these values do not differ much amongst them. Above all, they are in line with the estimates (again for Italy in the second post-war, but with different sources of data) by Forte and Magazzino (2011), Pevcin (2008), and Magazzino (2008). Moreover, it is interesting to underline that tax reforms undertaken in this period have shown a brake on growth. In addition, it has generated tax restrains rather than lightening.

The estimates with respect to the previous time intervals confirm the presence of a BARS curve (Table 4). Between 1862 and 1914, the optimal government size was equal to $13.96 \%$ which is in line with the government 
size of that historical period (Tanzi and Schuknecht, 2007). This occurs when the policies budget were inspired by orthodox (or neutral) finance. Leroy-Beaulieu (1879) argued that a tax pressure equal to $12 \%$ of domestic production was already exorbitant and gravid of the danger for growth and economic freedom.

\begin{tabular}{|c|c|c|c|c|c|}
\hline $\begin{array}{c}\text { Table } 4 . \\
\text { Estimates for the } \\
\text { BARS curve } \\
\text { (Italy, 1919- } \\
\text { 2008)Dependent } \\
\text { Variable: } \mathbf{y}\end{array}$ & 1919-1939 & 1946-1972 & 1973-1992 & 1993-2008 & $1973-2008$ \\
\hline G & $\begin{array}{l}6.0211^{*} \\
(3.1056)\end{array}$ & $\begin{array}{l}2.6106^{*} \\
(1.4747)\end{array}$ & $\begin{array}{c}15.4875^{* *} \\
(6.4367)\end{array}$ & $\begin{array}{l}14.8580^{*} \\
(9.3122)\end{array}$ & $\begin{array}{c}4.9463^{* * * *} \\
(1.1089)\end{array}$ \\
\hline$G^{2}$ & $\begin{array}{c}-15.3661^{*} \\
(8.2019)\end{array}$ & $\begin{array}{c}-5.7140 * * * \\
(2.0360)\end{array}$ & $\begin{array}{l}-22.9142 * \\
(11.4261)\end{array}$ & $\begin{array}{l}-20.9493^{*} \\
(12.7051)\end{array}$ & $\begin{array}{c}-6.5750 * * * \\
(3.2191)\end{array}$ \\
\hline $\mathrm{T}$ & $\begin{array}{c}6.8128 \\
(7.9333)\end{array}$ & $\begin{array}{l}-2.1202^{*} \\
(1.1874)\end{array}$ & $\begin{array}{c}-4.9513^{* * *} \\
(1.0607)\end{array}$ & $\begin{array}{c}-7.3659 * * * \\
(2.1236)\end{array}$ & $\begin{array}{c}-6.7141^{* * *} \\
(2.5046)\end{array}$ \\
\hline Fiscal Reforms & $\begin{array}{c}7.1931^{* * *} \\
(3.0175)\end{array}$ & $\begin{array}{l}2.7147^{*} \\
(1.5980)\end{array}$ & $\begin{array}{l}-0.5706 \\
(1.0977)\end{array}$ & $\begin{array}{c}0.0175 \\
(0.2789)\end{array}$ & $\begin{array}{c}0.0538 \\
(0.0736)\end{array}$ \\
\hline $\mathrm{p}$ & $\begin{array}{c}-0.1908 * * * \\
(0.0490)\end{array}$ & $\begin{array}{c}-0.9192 * * * \\
(0.0177)\end{array}$ & $\begin{array}{c}-0.7567 * * * \\
(0.0808)\end{array}$ & $\begin{array}{c}-0.6349 * \\
(0.3775)\end{array}$ & $\begin{array}{c}-0.5911^{* * * *} \\
(0.0857)\end{array}$ \\
\hline Population & $\begin{array}{l}12.9548^{*} \\
(6.8745)\end{array}$ & $\begin{array}{c}3.4621^{* * *} \\
(1.3159)\end{array}$ & $\begin{array}{c}21.9466 * * * \\
(0.1216)\end{array}$ & $\begin{array}{c}32.5681 \\
(30.6301)\end{array}$ & $\begin{array}{l}6.1155^{*} \\
(3.1701)\end{array}$ \\
\hline $\mathrm{u}$ & - & $\begin{array}{c}-0.5773 * * * \\
(0.0891)\end{array}$ & $\begin{array}{c}-1.3748^{* * * *} \\
(0.5238)\end{array}$ & $\begin{array}{l}-0.0217 \\
(0.2615)\end{array}$ & $\begin{array}{l}-0.1401^{*} \\
(0.0782)\end{array}$ \\
\hline Openness & - & $\begin{array}{c}5.5310 * * \\
(2.2927)\end{array}$ & $\begin{array}{c}22.4014 * * * \\
(6.2480)\end{array}$ & $\begin{array}{c}17.57691 * * * \\
(3.3392)\end{array}$ & $\begin{array}{l}-3.9690 \\
(4.5948)\end{array}$ \\
\hline $\mathrm{D}$ & $\begin{array}{l}-0.5653 * \\
(0.3277)\end{array}$ & $\begin{array}{l}1.4865^{*} \\
(0.8515)\end{array}$ & $\begin{array}{c}-0.3977 * * * \\
(0.0537)\end{array}$ & $\begin{array}{l}-0.0990 \\
(0.0844)\end{array}$ & $\begin{array}{l}-0.1547 \\
(0.1959)\end{array}$ \\
\hline B & $\begin{array}{l}-0.0230 \\
(0.0265)\end{array}$ & $\begin{array}{c}0.0453 \\
(0.1130)\end{array}$ & $\begin{array}{c}-0.7766^{* *} \\
(0.3518)\end{array}$ & $\begin{array}{c}-0.6312 * * * \\
(0.0328)\end{array}$ & $\begin{array}{c}-0.1459 * * \\
(0.0594)\end{array}$ \\
\hline Constant & $\begin{array}{l}-12.3832 \\
(7.8307) \\
\end{array}$ & $\begin{array}{c}-6.6083 * * * \\
(0.5367) \\
\end{array}$ & $\begin{array}{c}23.7629 * * * \\
(13.9887) \\
\end{array}$ & $\begin{array}{c}40.2839 \\
(31.5446) \\
\end{array}$ & $\begin{array}{r}6.7186 \\
(5.8412) \\
\end{array}$ \\
\hline $\mathrm{N}$ & 21 & 26 & 20 & 15 & 35 \\
\hline ARMA & $(0,1)$ & $(0,1)$ & $(1,1)$ & $(0,1)$ & $(0,0)$ \\
\hline Wald $\chi^{2}$ & $(0.0000)$ & $(0.0000)$ & $(0.0000)$ & $(0.0000)$ & $(0.0000)$ \\
\hline AIC & -120.3066 & -106.5408 & -88.5696 & -53.5277 & -155.1933 \\
\hline BIC & -128.6627 & -117.8636 & -98.5269 & -59.9002 & -167.6361 \\
\hline$l$ & 52.1533 & 44.2704 & 34.2848 & 17.7639 & 69.5966 \\
\hline$\overline{\mathrm{G}}$ & 21.21 & 28.49 & 35.43 & 46.38 & 49.81 \\
\hline $\mathrm{G}^{*}$ & 19.59 & 22.84 & 33.79 & 35.46 & 37.61 \\
\hline $\mathrm{G}^{*}-\overline{\mathrm{G}}$ & -1.62 & -5.65 & -1.64 & -10.92 & -12.20 \\
\hline
\end{tabular}

Notes: Robust Standard Errors in parentheses. Significance levels: * 10\%, ** 5\%, *** 1\%.

In those years, the average ratio of expenditure/GDP was still below both values mentioned above (10.69\%). In the inter-war period, this threshold rises to $24.42 \%$. This was in line with the $25 \%$ held by Keynes 
(1936) as a tolerable maximum. In addition, the average share amounted to the same values (26.21\%). Finally, with the Second Republic, marked differences were recorded between optimal expenditure (40.60\%) and its average (47.09\%). This was with obvious negative effects on economic growth as was previously highlighted.

Table 5. Estimates for the BARS curve (Italy, 1861-2008)

\begin{tabular}{|c|c|c|c|c|c|c|}
\hline \multirow{2}{*}{$\begin{array}{l}\text { Dependent } \\
\text { Variable: y }\end{array}$} & \multicolumn{2}{|c|}{ 1861-1939 } & \multicolumn{2}{|c|}{ 1946-2008 } & \multicolumn{2}{|c|}{ 1861-2008 } \\
\hline & 1a & 1b & $2 \mathbf{a}$ & $2 \mathbf{b}$ & За & $3 c$ \\
\hline G & $\begin{array}{l}-0.0060 \\
(0.0146)\end{array}$ & $\begin{array}{l}0.0819 * \\
(0.0482)\end{array}$ & $\underset{* * *}{0.1586}$ & $\begin{array}{c}0.6091 \\
* * *\end{array}$ & $\begin{array}{c}0.0217 \\
* * *\end{array}$ & $\begin{array}{c}0.6301 \\
* * *\end{array}$ \\
\hline & & & $(0.0362)$ & $(0.0675)$ & $(0.0061)$ & $(0.0360)$ \\
\hline $\mathrm{G}^{2}$ & - & $\begin{array}{c}-0.2375 \\
* *\end{array}$ & - & $\begin{array}{c}-1.0361 \\
* * *\end{array}$ & - & $\begin{array}{c}-1.5263 \\
* * *\end{array}$ \\
\hline & & (0.1154) & & $(0.3053)$ & & $(0.2621)$ \\
\hline Population & $\begin{array}{c}0.2306 * * \\
(0.0995)\end{array}$ & $\begin{array}{c}0.2231 * * \\
(0.1024)\end{array}$ & $\begin{array}{c}2.4363 \\
* * *\end{array}$ & $\begin{array}{c}3.4840 \\
* * *\end{array}$ & $\begin{array}{c}-0.0236 \\
(0.0650)\end{array}$ & $\begin{array}{c}0.0258 \\
(0.0687)\end{array}$ \\
\hline $\mathrm{p}$ & $\begin{array}{c}-0.0066 \\
(0.0276)\end{array}$ & $\begin{array}{c}-0.0013 \\
(0.0324)\end{array}$ & $\begin{array}{c}(0.3065) \\
-0.0247 \\
(0.0181)\end{array}$ & $\begin{array}{c}(0.4178) \\
-0.0259 \\
(0.0166)\end{array}$ & $\begin{array}{c}-0.0508 \\
* * *\end{array}$ & $\begin{array}{c}-0.0581 \\
* * *\end{array}$ \\
\hline Post WWI & $\begin{array}{c}0.0376 \\
(0.0376)\end{array}$ & $\begin{array}{c}0.0281 \\
(0.0485)\end{array}$ & - & - & $\begin{array}{c}(0.0094) \\
0.0565 \\
* * *\end{array}$ & $\begin{array}{c}(0.0100) \\
0.0753 \\
* * *\end{array}$ \\
\hline Post WWII & 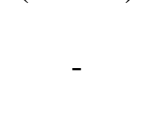 & 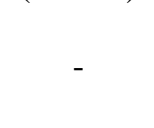 & - & - & $\begin{array}{c}(0.0210) \\
0.3035 \\
* * *\end{array}$ & $\begin{array}{c}(0.0228) \\
0.3335 \\
* * *\end{array}$ \\
\hline Post 1992 & - & - & $\begin{array}{c}0.0372 \\
* * * \\
(0.0127)\end{array}$ & $\begin{array}{c}0.0247 * * \\
(0.0123)\end{array}$ & $\begin{array}{c}(0.0395) \\
0.0536 \\
* * * \\
(0.0199)\end{array}$ & $\begin{array}{l}(0.0418) \\
0.0366 * \\
(0.0214)\end{array}$ \\
\hline Constant & $\begin{array}{c}-0.8494 * \\
(0.5057)\end{array}$ & $\begin{array}{c}-0.7502 \\
(0.5987)\end{array}$ & $\begin{array}{c}-21.1920 \\
* * * \\
(2.8749) \\
\end{array}$ & $\begin{array}{c}-31.5805 \\
* * * \\
(4.0422) \\
\end{array}$ & $\begin{array}{c}0.2394 \\
(0.5889)\end{array}$ & $\begin{array}{c}-0.3591 \\
(0.6529)\end{array}$ \\
\hline $\mathrm{N}$ & 77 & 77 & 62 & 62 & 145 & 145 \\
\hline Wald $\chi^{2}$ & $\begin{array}{l}5437.76 \\
(0.0000)\end{array}$ & $\begin{array}{l}5444.58 \\
(0.0000)\end{array}$ & $\begin{array}{c}35097.87 \\
(0.0000)\end{array}$ & $\begin{array}{c}41630.24 \\
(0.0000)\end{array}$ & $\begin{array}{c}63603.07 \\
(0.0000)\end{array}$ & $\begin{array}{c}65375.43 \\
(0.0000)\end{array}$ \\
\hline Adj. $R^{2}$ & 0.9560 & 0.9561 & 0.9782 & 0.9785 & 0.9777 & 0.9778 \\
\hline RMSE & 0.0411 & 0.0413 & 0.0291 & 0.0270 & 0.0515 & 0.0510 \\
\hline AIC & -3.4722 & -3.4474 & -4.1423 & -4.2804 & -3.0340 & -3.0536 \\
\hline HQIC & -3.3991 & -3.3622 & -4.0614 & -4.1861 & -2.9732 & -2.9785 \\
\hline l & 139.6788 & 139.7264 & 134.4098 & 139.6925 & 228.3977 & 230.3859 \\
\hline$\overline{\mathrm{G}}$ & 15.0264 & 15.0264 & 39.5827 & 39.5827 & 26.4080 & 26.4080 \\
\hline $\mathrm{G}^{*}$ & & 17.25 & & 29.39 & & 20.64 \\
\hline $\mathrm{G}^{*}-\overline{\mathrm{G}}$ & & 2.22 & & -10.19 & & -5.77 \\
\hline
\end{tabular}

Notes: Robust Standard Errors in parentheses. Significance levels: * 10\%, ** 5\%, *** 1\%.

\section{Concluding Remarks and Policy Implications}

Our results show the presence of a non-linear relationship between the size of public sector (measured by the share of government expenditure 
over GDP) and the economic growth rate for Italy. In general, regardless of the data used - here, those of Forte (2011), in other analyses those of the European Commission - and the temporal subdivisions, the presence of a parabolic dynamic between variables emerges.

Therefore, for Italy, a space of considerable manoeuvre might be evidenced since growth incentives can be pursued for a dual route. Both expenditure and tax cuts concur to the strengthening of economic activity in the first case as BARS effect, in the second as a supply-side effect, and a demand effect compatible with the balance of payment equilibrium. Reducing the tax burden, if a Laffer effect is triggered, it would improve the state of public finances by increasing revenue (EC, 2011).

It should be noted that the prescriptions of policies arising from these analyses cast doubt about the existence of a trade-off between austerity and growth that the policy-makers would face. This is because the plans of fiscal consolidation - if the BARS and Laffer curves worked - would contribute in achieving both objectives.

The previous results should be combined with those concerning the composition of expenditure (Forte and Magazzino, 2014; Magazzino, 2012b). Since no item of public expenditure Granger causes aggregate income, the cuts in public expenditure should not have a negative impact on growth. Therefore, reallocating the public resources from an unproductive to a more productive items (R\&D or public investment), it would stimulate long-run economic growth. In other words, in modifying the public expenditure composition and varying the volume of each chapter, one could obtain the effect of a more pronounced growth.

Moreover, public expenditure cuts contribute to the achievement of the primary balance surplus and debt reduction, within a wider framework of fiscal consolidation. Without mentioning the relevant structural reforms of which Italy has a clear necessity, they were able to restructure public expenditure and promote economic growth: the Welfare State reform, the revision of the tax system, the reduction of the fiscal churning, the justice reform, the reorganization of pension system, the labour market reform, the revision of education system, and the new institutional architecture with a simplification of policy framework (Bavetta and Navarra, 2012). Nevertheless, these subjects were beyond the scope of this study.

\section{References:}

Afonso \& Jalles (2011). Economic performance and government size, ECB Working Paper, 1399, November.

Alesina \& Ardagna (2009). Large changes in fiscal policy: Taxes versus spending, NBER Working Paper, 15438.

Armey (1995). The Freedom Revolution, Washington, D.C.: Regnery 
Publishing Co.

Balassone et al. (2011). Public Debt and Economic Growth in Italy, Bank of Italy - Economic History Working Papers, 11, October.

Barrios et al. (2011). EU fiscal consolidation after the financial crisis, Lesson from past experiences, EC Economic Papers, 418, July.

Barro (1989). A Cross-Country Study of Growth, Saving and Government, NBER Working Paper, 2855.

Barro (1990). Economic growth in a cross section of countries, Quarterly Journal of Economics, 106, 2, 407-443.

Bavetta \& Navarra (2012). The economics of freedom, Cambridge: Cambridge University Press.

Buiatti et al. (2014). The origins of the public debt of Italy: Geographically dispersed interests?, Journal of Policy Modeling, 36(1), 43-62.

Blume \& Voigt (2013). The economic effects of constitutional budget institutions, European Journal of Political Economy, 29, 236-251.

Cecchetti et al. (2011). The real effects of debt, BIS Working Paper, 352, September.

Cunctator \& Magazzino (2012). Il trade-off tra crescita economica e rigore fiscale, Return-On-Intelligence, Istituto Italiano di Studi Strategici, 7, July.

Dalena \& Magazzino (2012). Public Expenditure and Revenue in Italy, 1862-1993, Economic Notes, 41, 3, 145-172.

Engen \& Skinner (1992). Fiscal Policy and Economic Growth, NBER Working Paper, 4223.

European Commission (2010). Public finances in EMU - 2010, European Economy, 4.

European Commission (2011). Public finances in EMU - 2011, European Economy, 3.

European Commission (2013a). Public finances in EMU - 2013, European Economy, 4.

European Commission (2013b). Council recommendation on Italy 2013 national reform programme and delivering a Council opinion on Italy's stability programme for 2012-2017, http://ec.europa.eu/europe2020/pdf/nd/csr2013_italy_en.pdf.

Forte (2011). L'economia italiana dal Risorgimento ad oggi, 1861-2011, Siena: Cantagalli.

Forte \& Magazzino (2011). Optimal Size Government and Economic Growth in EU Countries, Journal of Analytical and Institutional Economics, XXVIII, 3, 295-321.

Forte \& Magazzino (2014). Economic growth and fiscal consolidation: the optimal mix between current and investment public expenditure. The case of Europe, in Forte, F., Mudambi, R., Navarra, P., (eds.). Handbook of Alternative Theories of Public Economics, Cheltenham: Edward Elgar. 
Grier \& Tullock (1989). An Empirical Analysis of Cross-national Economic Growth, 1951-1980, Journal of Monetary Economics, 24, 2, 259-276.

Grossman (1987). The optimal size of Government, Public Choice, 53, 131147.

Grossman (1988). Growth in government and economic growth: The Australian experience, Australian Economic Papers, 27, 33-43.

Hsieh \& Lai (1994). Government spending and economic growth: the G-7 experience, Applied Economics, 26, 535-542.

Kahn (2011). Can We Determine the Optimal Size of Government?, CATO Institute - Development Policy Briefing Paper, 7, September.

Keynes (1936). The General Theory of Employment, Interest and Money, London: Macmillan.

Kormendi \& Meguire (1985). Macroeconomic determinants of growth: cross-country evidence, Journal of Monetary Economics, 16, 2, 141-163.

Kourtellos et al. (2013). The effect of public debt on growth in multiple regimes, Journal of Macroeconomics, 38, 35-43.

Landau (1983). Government and Economic Growth in The Less Developed Countries: An Empirical Study for 1960-1980, The University of Chicago Press, 35, 1, 35-75.

Leroy Beaulieu (1879). Traité de la science des finances, Paris.

Magazzino (2008). Modelli interpretativi della dinamica della spesa pubblica e 'curva di Armey': il caso italiano, 1862-2001, Notizie di Politeia, XXIV, 92, 45-60.

Magazzino (2010). La politica economica di Margaret Thatcher, Milano: Franco Angeli.

Magazzino (2012a). Politiche di bilancio e crescita economica, Torino: Giappichelli.

Magazzino (2012b). Wagner versus Keynes: Public Spending and National Income in Italy at a Disaggregated Level, Journal of Policy Modeling, 34, 6, November-December, 890-905.

Magazzino (2012c). Wagner's Law and Augmented Wagner's Law in EU27. A Time-Series Analysis on Stationarity, Cointegration and Causality, International Research Journal of Finance and Economics, 89, April, 205220.

Peacock \& Wiseman (1961). The Growth of Public Expenditure in the United Kingdom, Princeton: Princeton University Press.

Pevcin (2008). The Issue Of The Economically Preferred Size Of Government, E.A.B.R. \& T.L.C. Conference Proceedings, Salzburg.

Rahn \& Fox (1996). What Is the Optimum Size of Government, Vernon K. Krieble Foundation.

Ram (1986). Government size and economic growth: a new framework and some evidence from cross-section and time series data, American Economic 
Review, 76, 191-203.

Reinhart \& Rogoff (2010). Growth in a Time of Debt, American Economic Review, May.

Rubinson (1977). Dependency, government revenue and economic growth: 1955-1970, Studies in Comparative International Development, 12, 3-28.

Scully (1994. What is the optimal Size of government in the US?, National Center for Policy Analysis, Policy Report, 188.

Scully (1995). The "Growth Tax" in the United States, Public Choice, 85, 12, 71-80.

Tanzi \& Schuknecht (2007). La spesa pubblica nel XX secolo. Una prospettiva globale, Firenze: Firenze University Press.

Teles \& Mussolini (2014). Public debt and the limits of fiscal policy to increase economic growth, European Economic Review, 66, 1-15.

Vedder \& Gallaway (1998). Government Size and Economic Growth, Joint Economic Committee.

Wöhlbier et al. (2014). Consolidation on the revenue side and growthfriendly tax structures: an indicator based approach, European Economy Economic Papers, 513, February. 


\section{Appendix}

Table A. Exploratory data analyses (Italy, 1861-2008)

\begin{tabular}{|c|c|c|c|c|c|}
\hline \multicolumn{6}{|c|}{ 1861-1876 } \\
\hline Variable & $\mathbf{C V}$ & Skewness & Median & IQR & SD \\
\hline Economic growth rate & 3.2545 & 0.9174 & 2.7608 & 5.8915 & 7.1611 \\
\hline Public expenditure/GDP & 0.5387 & 0.6114 & 15.2095 & 18.8061 & 10.821 \\
\hline Public revenue/GDP & 0.4663 & 0.6403 & 12.8458 & 15.3227 & 8.1528 \\
\hline Effective deficit/GDP & -1.6375 & -2.1413 & -1.1815 & 5.6642 & 6.9637 \\
\hline Public debt/GDP & 0.4056 & 0.0385 & 75.9535 & 44.5971 & 29.5563 \\
\hline Inflation & 4.0474 & 8.1562 & 2.1289 & 7.0422 & 34.8721 \\
\hline Population & 0.2388 & 0.1570 & 37023 & 15596 & 9285.91 \\
\hline \multicolumn{6}{|c|}{$1877-1895$} \\
\hline Economic growth rate & 5.1324 & -0.2472 & 0.7696 & 4.0353 & 3.2563 \\
\hline Public expenditure/GDP & 0.1329 & 0.3078 & 10.9724 & 2.0093 & 1.4676 \\
\hline Public revenue/GDP & 0.1218 & 0.4951 & 11.0643 & 1.6773 & 1.3459 \\
\hline Effective deficit/GDP & -2.1325 & -0.8478 & -0.1099 & 0.5341 & 0.4292 \\
\hline Public debt/GDP & 0.1056 & -0.3456 & 91.6181 & 13.6611 & 9.6999 \\
\hline Inflation & -3.2716 & 0.1440 & -1.5192 & 5.8852 & 3.3832 \\
\hline Population & 0.0394 & 0.0251 & 30101 & 2208 & 1185.05 \\
\hline \multicolumn{6}{|c|}{ 1896-1914 } \\
\hline Economic growth rate & 2.6920 & -0.1176 & 1.6319 & 6.9653 & 5.6956 \\
\hline Public expenditure/GDP & 0.1314 & 2.7907 & 11.1354 & 1.3477 & 1.4932 \\
\hline Public revenue/GDP & 0.0680 & 0.5326 & 11.5154 & 1.3678 & 0.7773 \\
\hline Effective deficit/GDP & -7.5627 & -3.5542 & 0.2268 & 0.6018 & 1.4019 \\
\hline Public debt/GDP & 0.1560 & 0.2829 & 87.0792 & 21.7926 & 13.3320 \\
\hline Inflation & 1.6530 & 0.6818 & 0.4435 & 2.3703 & 1.4125 \\
\hline Population & 0.0421 & 0.1100 & 34205 & 2779 & 1443.29 \\
\hline \multicolumn{6}{|c|}{$1919-1939$} \\
\hline Economic growth rate & 1.6320 & -0.1243 & 0.9172 & 6.0165 & 4.0453 \\
\hline Public expenditure/GDP & 0.3779 & 0.7439 & 19.5085 & 10.5676 & 8.0150 \\
\hline Public revenue/GDP & 0.3171 & 1.3734 & 18.0678 & 4.2508 & 6.2206 \\
\hline Effective deficit/GDP & -1.1351 & -1.0639 & -3.2797 & 7.5358 & 5.3639 \\
\hline Public debt/GDP & 0.2555 & 0.7129 & 90.7814 & 49.9243 & 25.6393 \\
\hline Inflation & 3.2132 & 1.1910 & 1.5293 & 10.8532 & 9.7148 \\
\hline Population & 0.0579 & -0.4350 & 41202 & 3281 & 2377.93 \\
\hline \multicolumn{6}{|c|}{ 1946-1972 } \\
\hline Economic growth rate & 1.1386 & 4.3673 & 5.6227 & 2.1507 & 8.2095 \\
\hline Public expenditure/GDP & 0.1765 & -0.5013 & 28.4000 & 6.3999 & 5.0294 \\
\hline Public revenue/GDP & 0.2476 & -1.1737 & 27.3000 & 7.3000 & 6.1570 \\
\hline Effective deficit/GDP & -0.8559 & -1.5785 & -2.4742 & 2.8335 & 2.7623 \\
\hline Public debt/GDP & 0.1650 & 1.2035 & 30.9666 & 4.7109 & 5.2070 \\
\hline Inflation & 1.8490 & 4.2230 & 4.2482 & 3.6188 & 11.7121 \\
\hline Population & 0.0518 & 0.1182 & 50023 & 4713 & 2598.90 \\
\hline \multicolumn{6}{|c|}{ 1973-1992 } \\
\hline Economic growth rate & 0.7679 & -0.0023 & 2.9809 & 2.3984 & 2.2256 \\
\hline Public expenditure/GDP & 0.1314 & -0.2669 & 48.4000 & 9.6999 & 6.0921 \\
\hline Public revenue/GDP & 0.1305 & 0.0468 & 37.0751 & 7.0779 & 4.6818 \\
\hline Effective deficit/GDP & -0.2755 & -0.1709 & -10.7359 & 4.9351 & 3.0262 \\
\hline Public debt/GDP & 0.2516 & 0.3784 & 66.2730 & 33.5507 & 18.2024 \\
\hline Inflation & 0.4699 & 0.0704 & 11.5132 & 10.5000 & 5.6441 \\
\hline Population & 0.0076 & -1.4264 & 56564 & 474.50 & 426.49 \\
\hline \multicolumn{6}{|c|}{ 1993-2008 } \\
\hline Economic growth rate & 0.9668 & -0.2818 & 1.4869 & 1.3819 & 1.2312 \\
\hline Public expenditure/GDP & 0.0550 & 1.1336 & 48.8000 & 3.3500 & 2.7414 \\
\hline Public revenue/GDP & 0.0225 & 0.2808 & 44.9959 & 1.6373 & 1.0149 \\
\hline Effective deficit/GDP & -0.8877 & -0.6210 & -2.5424 & 3.7764 & 2.9912 \\
\hline Public debt/GDP & 0.0606 & 0.4043 & 108.9798 & 11.1342 & 6.7447 \\
\hline Inflation & 0.4290 & 1.0677 & 2.4327 & 2.1676 & 1.1452 \\
\hline Population & 0.0194 & 0.9445 & 56977.50 & 1717 & 1121.95 \\
\hline
\end{tabular}

Notes: CV: coefficient of variation; IQR: Inter-Quartile Range; SD: Standard Deviation. 
Table B. Correlation matrix (Italy, 1861-2008)

\begin{tabular}{|c|c|c|c|c|c|c|c|c|c|}
\hline & $\overline{\mathrm{y}}$ & $\bar{G}$ & $\mathrm{~T}$ & $\mathrm{D}$ & $\mathrm{B}$ & p & 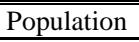 & $\overline{\mathrm{u}}$ & Openness \\
\hline $\mathrm{y}$ & 1 & & & & & & & & \\
\hline G & $\begin{array}{c}- \\
0.0265\end{array}$ & 1 & & & & & & & \\
\hline $\mathrm{T}$ & $\begin{array}{c}- \\
0.0513\end{array}$ & 0.9565 & 1 & & & & & & \\
\hline D & $\begin{array}{c}- \\
0.2309\end{array}$ & $\begin{array}{c}- \\
0.5581\end{array}$ & $\begin{array}{c}- \\
0.3471\end{array}$ & 1 & & & & & \\
\hline B & $\begin{array}{c}- \\
0.3119\end{array}$ & 0.1165 & $\begin{array}{c}- \\
0.1426\end{array}$ & $\begin{array}{c}- \\
0.0931\end{array}$ & 1 & & & & \\
\hline $\mathrm{p}$ & $\begin{array}{c}- \\
0.4570\end{array}$ & 0.1537 & $\begin{array}{c}- \\
0.0343\end{array}$ & $\begin{array}{c}- \\
0.4967\end{array}$ & $\begin{array}{c}- \\
0.0083\end{array}$ & 1 & & & \\
\hline Population & 0.1261 & 0.8577 & 0.8376 & $\begin{array}{c}- \\
0.3137\end{array}$ & $\begin{array}{c}- \\
0.1056\end{array}$ & 0.1236 & 1 & & \\
\hline $\mathrm{u}$ & $\begin{array}{c}- \\
0.3284\end{array}$ & 0.5750 & 0.4597 & $\begin{array}{c}- \\
0.4148\end{array}$ & 0.5882 & 0.0007 & 0.3562 & 1 & \\
\hline Openness & $\begin{array}{c}- \\
0.6976\end{array}$ & 0.8408 & 0.9417 & $\begin{array}{c}- \\
0.0899\end{array}$ & 0.9178 & $\begin{array}{c}- \\
0.0877\end{array}$ & 0.8999 & 0.3763 & 1 \\
\hline
\end{tabular}

Notes: Bonferroni’s adjustment applied.

Figure 2. Public debt and fluctuating debt (\%, Italy, 1862-2008)

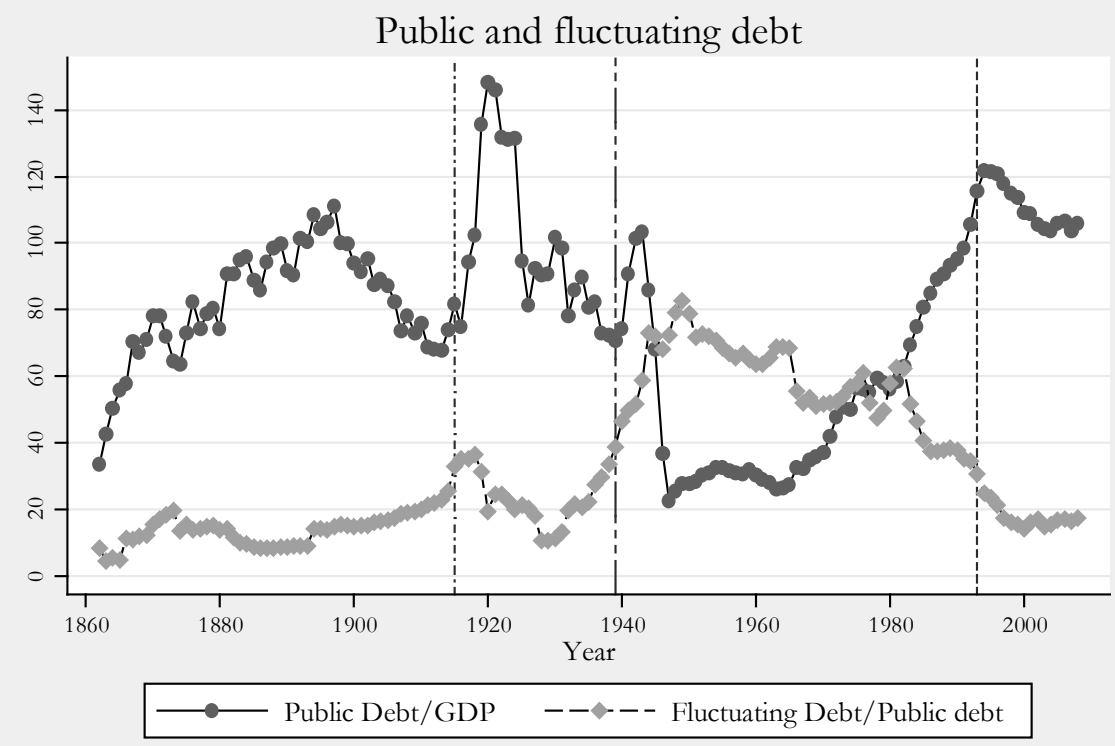

Source: Forte (2011) 
Figure 3. Effective public deficit and unemployment rate (\%, Italy, 1945-2008)

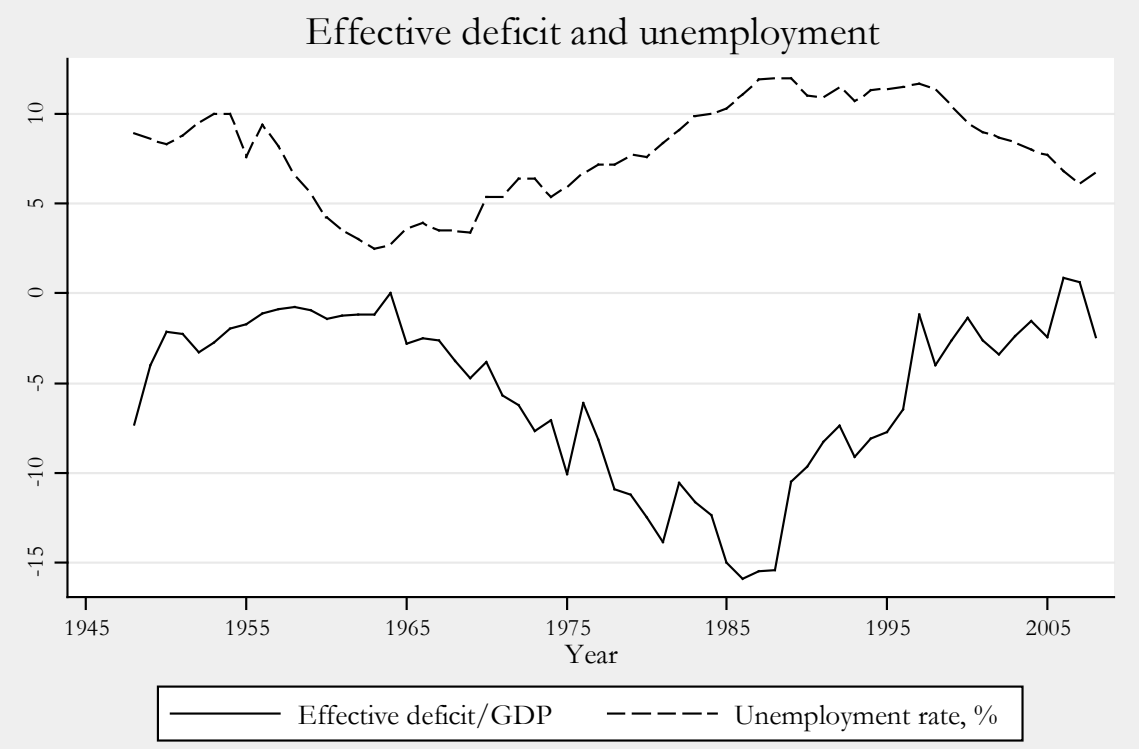

Source: Forte (2011) 